\title{
Acanthocytosis, normolipoproteinaemia and multiple tics
}

\author{
E. M. R. CRITCHLEY \\ B.M., M.R.C.P. \\ Consultant Neurologist, Preston Royal Infirmary \\ J. T. NiCHOLSON \\ B.Sc. \\ Department of Chemistry and Biology, \\ Harris College, Preston
}

\author{
J. J. BETTS \\ B.Sc., Ph.D.(Cantab.), Ph.D.(Birm.), F.R.I.C. \\ Head of the Department of Chemistry and Biology, \\ Harris College, Preston \\ D. J. WeATHERALL \\ M.D., F.R.C.P., M.R.C.Path. \\ Reader in Haematology, Department of Medicine, \\ University of Liverpool
}

neglecting her child. At times she would have difficulty in coordinating movements and would bump into objects or, when sitting quietly, suddenly fall to the floor. Her husband became increasingly irritated by grunting noises of which at first she was unaware. During her second pregnancy she developed hypertension and in November 1968 gave birth prematurely at home after 7 months' gestation. She was unable to get to the telephone to call the doctor. On her own volition she had attended the ENT and Psychiatric clinics in 1968 complaining of intermittent difficulty in swallowing, thinking that it was due to cancer. There was no history suggestive of steatorrhoea.

When examined in September 1969 she was noted to be thin with high arched feet, $5 \mathrm{ft} 4$ in in height and weighing only $126 \mathrm{lb}$. She was alert and oriented, yet appeared unkempt and dishevelled. Many of her symptoms distressed her but there were others of which she was apparently unaware until her attention had been directed to them. Most disturbing were the wide variety of oro-facial tics. At times these appeared compulsive or even hysterical. They were continually present during waking hours though fluctuating in severity from day to day and partially improved by benzhexol and diazepam. Her speech was dysarthric, partly broken by the involuntary movements. She would also grunt, suck, cluck, make repetitive sounds, bite her tongue and lower lip (Fig. 1), or struggle to control the pooling of saliva. The involuntary limb movements were sometimes dystonic and sometimes choreiform with hyperextension and flexion of her trunk and throwing out of an arm or leg. She performed purposive movements fairly well despite an apparent loss of manual and finger dexterity. Her visual acuity was normal, the visual fields full and there was no evidence of retinitis pigmentosa. There were no Kayser-Fleischer rings and the pupils reacted to light and accommodation. There was no 


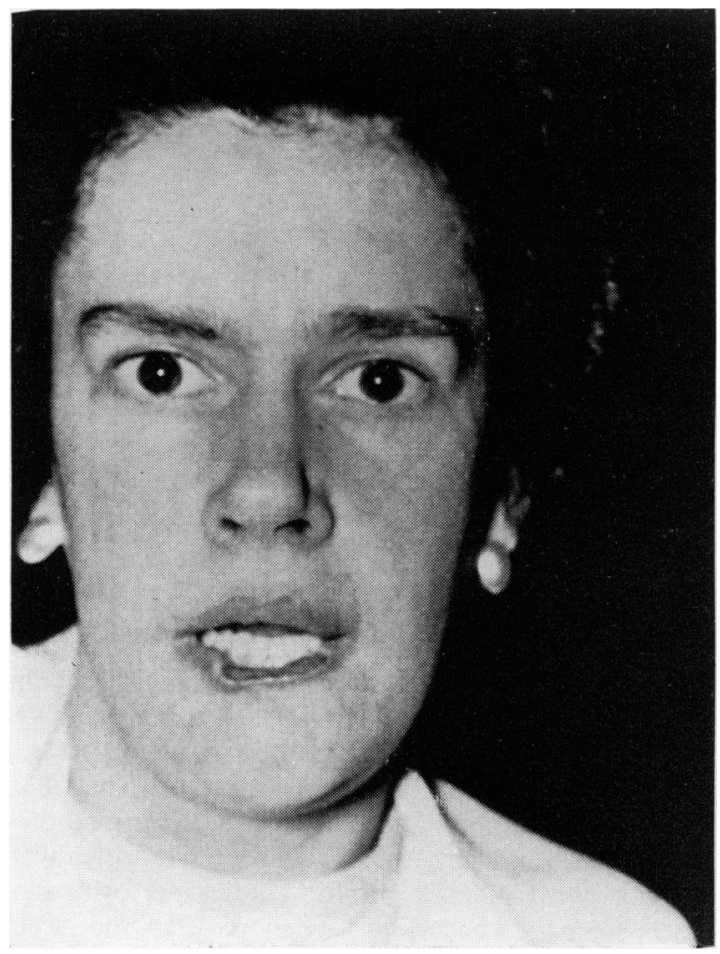

FIG. 1. Proband. Note especially her bitten lip.

nystagmus. The jaw jerk was present. She had normal tone and power in her limbs without wasting. The reflexes were just present and the plantars were flexor. She was not ataxic and sensation was intact. She could hop on either foot. Romberg's test was negative. Her blood pressure was $160 / 100 \mathrm{mmHg}$. Heart, chest and abdomen were normal and there were no glands palpable.

\section{Investigations}

The blood indices were as follows: $\mathrm{Hb} 13 \cdot 1 \mathrm{~g} / 100$ $\mathrm{ml}, \mathrm{MCHC} 34 \%$, WCC $4400 / \mu \mathrm{l}$ (normal differential), platelets $182,000 / \mu l$, reticulocytes $3 \%$, ESR (Westergren) $8 \mathrm{~mm}$ in $1 \mathrm{hr}$. A Romanowsky stained blood film showed acanthocytosis and rouleaux formation (Fig. 2). In a fresh saline preparation acanthocytes made up $40-60 \%$ of the red cell population. The red cell deformity was corrected by the addition of $20 \%$ albumin or the non-ionic detergent, Tween 80 . No intracellular inclusions were noted either in wet preparations or after incubation with methyl violet. The red cell osmotic fragility, incubated and nonincubated, was normal but a slight increase in autohaemolysis was noted after $48 \mathrm{hr}$ incubation. This was corrected by the addition of ATP. The acanthocytes stood out well under the scanning electron microscope (Figs. 3 and 4). They comprised about

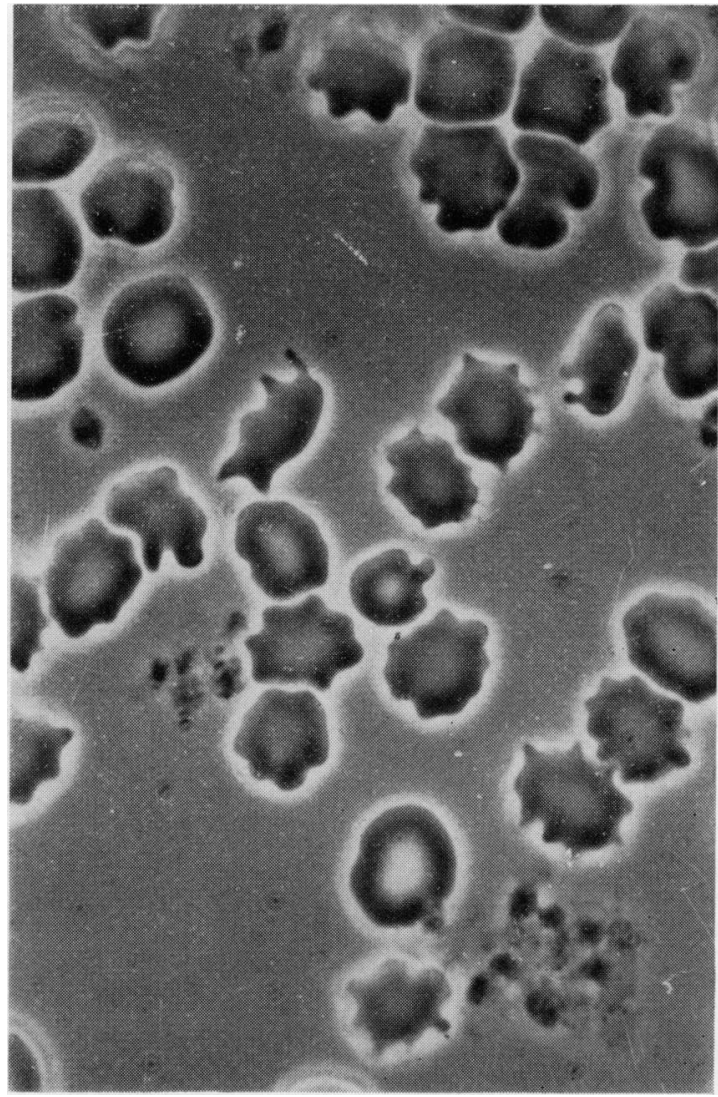

FIG. 2. Wet preparation to show acanthocytes, light microscopy, $\times 510$.

$45 \%$ of the cells, the other cells appeared normal. No membrane defects were seen.

The serum bilirubin was normal $(0.5 \mathrm{mg} / 100 \mathrm{ml})$, but a slight reduction in haptoglobin was noted on starch gel electrophoresis. The levels of erythrocyte glucose-6-phosphate dehydrogenase, creatinine phosphokinase and triose phosphate isomerase were normal or slightly elevated. Haemoglobin electrophoresis and serum vitamin $B_{12}$ and folate levels were also normal.

The biochemical studies were normal apart from an increased fibrinogen level at $813 \mathrm{mg} / 100 \mathrm{ml}$. The serum cholesterol was $225 \mathrm{mg} / 100 \mathrm{ml}$, vitamin A 26 micrograms $/ 100 \mathrm{ml}$, fasting vitamin E $1.2 \mathrm{mg} / 100$ $\mathrm{ml}$; the total serum proteins were normal at 7.0 $\mathrm{g} / 100 \mathrm{ml}$ with a raised globulin fraction on electrophoresis. Using paper electrophoresis the alphalipoprotein was $271 \mathrm{mg} / 100 \mathrm{ml}$ and beta-lipoprotein slightly raised at $740 \mathrm{mg} / 100 \mathrm{ml}$. Serum triglycerides were also estimated nephelometrically by the method of Stone \& Thorp (1966), and the lipoprotein pattern was determined as described by Stone et al.(1970). The 


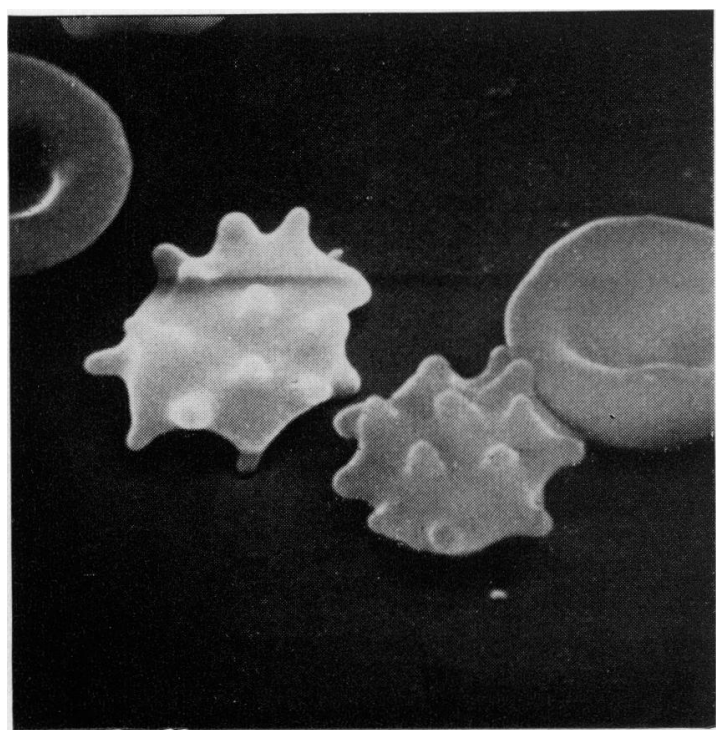

FIG. 3. Electron microscopy, $\times 4900$.

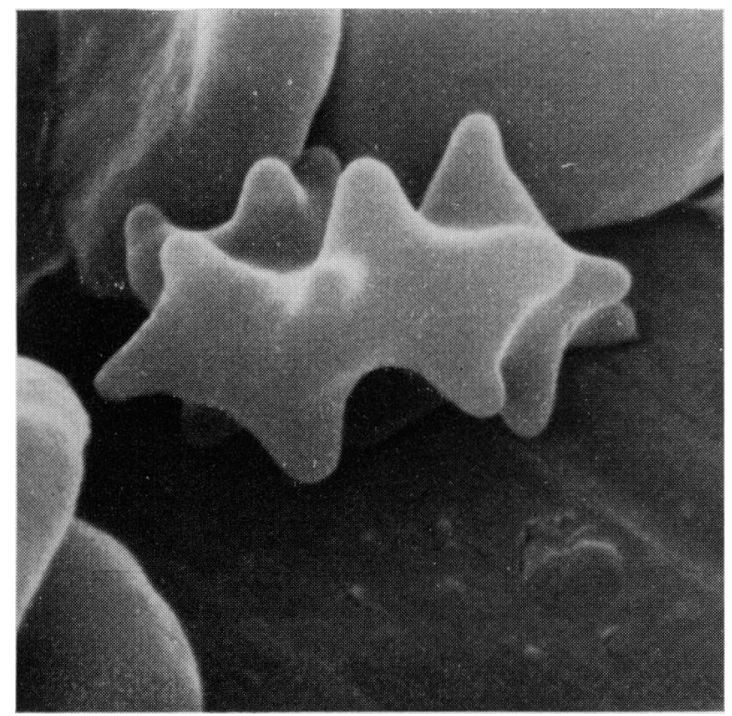

FIG. 4. Electron microscopy, $\times 12,800$.

results are shown in Table 1 . The serum electrolytes were normal: sodium $138 \mathrm{mEq} / \mathrm{l}$, potassium 4.5 $\mathrm{mEq} / \mathrm{l}$, chlorides $101 \mathrm{mEq} / \mathrm{l}$, calcium $9.8 \mathrm{mg} / 100 \mathrm{ml}$, and magnesium $3.4 \mathrm{mg} / 100 \mathrm{ml}$, with serum urea 34 $\mathrm{mg} / 100 \mathrm{ml}$, glucose $138 \mathrm{mg} / 100 \mathrm{ml}$ and creatinine 0.6 $\mathrm{mg} / 100 \mathrm{ml}$. The serum iron was $120 \mu \mathrm{g} / 100 \mathrm{ml}$, copper $147 \mu \mathrm{g} / 100 \mathrm{ml}$ and copper oxidase 395 units. The creatinine clearance was $119 \mathrm{ml} / \mathrm{min}$, without aminoaciduria and the faecal fat excretion was $3.4 \mathrm{~g} / 24 \mathrm{hr}$.
TABLE 1

\begin{tabular}{|c|c|c|}
\hline \multirow[t]{2}{*}{ Estimation } & \multicolumn{2}{|c|}{$\begin{array}{c}\text { Concentration in } \mathrm{mg} / 100 \mathrm{ml} \\
\text { of serum }\end{array}$} \\
\hline & (1) & (2) \\
\hline Total serum cholesterol & 198 & 246 \\
\hline Serum triglycerides & 158 & 116 \\
\hline Beta lipoproteins & & \\
\hline$\left(\mathrm{S}_{\mathrm{f}} 0-20\right)$ & 370 (Normal) & 481 (Normal) \\
\hline $\begin{array}{l}\text { Pre-beta lipoproteins } \\
\left(\mathrm{S}_{\mathrm{f}} 20-400\right)\end{array}$ & 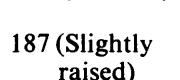 & 132 (Normal) \\
\hline Chylomicrons $\left(S_{f}>400\right)$ & 6 (Normal) & 8 (Normal) \\
\hline
\end{tabular}

Psychometric tests were performed on two occasions. The verbal I.Q. (Wechsler Adult Intelligence Scale) was 91 , performance 81 and full scale 86 . The Minnesota perceptuo-diagnostic test at 58 and the scatter of the Wechsler subtests suggested organic deterioration. This was not confirmed by pneumoencephalography which showed a normal ventricular system with intact caudate bulges. The CSF showed only $1 \mathrm{wbc} / \mu \mathrm{l}$ and a protein content of $15 \mathrm{mg} / 100 \mathrm{ml}$. The Wassermann and Lange reactions were negative. Electromyographic and nerve conduction studies, electrocardiography, muscle and liver biopsies were all normal. Cinematographic studies performed on two separate occasions when swallowing thick barium confirmed the difficulty in initiating deglutition and showed lack of co-ordination, weakness and flaccidity involving the soft palate and hypopharynx.

No acanthocytes were seen in the peripheral blood of her brother, father or two children. The presence of a serum factor affecting platelet function in this condition is the subject of a separate report (Betts, Critchley \& Nicholson, 1970).

\section{Discussion}

The normolipoproteinaemic syndrome differs from the two other neurological disorders associated with abnormal red cells in that there is no evidence of a concurrent disturbance of lipid metabolism. The disturbance of lipid metabolism seen in abetalipoproteinaemia is severe with impaired transport of fats across cell membranes and a decrease in all serum lipids with absence of the betalipoprotein moiety (Salt et al., 1960), and in some cases an accompanying abnormality in the red cell phospholipids (Phillips, 1962). The clinical presentation resembles that of Friedreich's ataxia. As only one family has been reported with familial hypo-betalipoproteinaemia, observations on this syndrome are necessarily limited. The clinical manifestations simulate multiple sclerosis, the serum lipids are reduced and the red cells readily resume a normal shape in hyperlipaemic solutions (Mars et al., 1969).

Historically it had been assumed that the present 
syndrome also formed part of the spectrum of lipid abnormality. Kuo \& Bassett (1962) originally presented the New England family as an example of hypo-betalipoproteinaemia. The younger brother had had loose stools since childhood with three times the normal amount of fat in the faeces $(18 \mathrm{~g} / 24 \mathrm{hr})$, and loose stools were seen in most of the acanthocytotic but neurologically normal relatives. However, repeated investigations subsequently showed normal lipoprotein levels and intestinal biopsies were likewise normal. Neither the present patient nor any member of the Kentucky family (Critchley et al., 1968) had a history of steatorrhoea or loose stools. The acanthocytes of this syndrome are stable in hypo- and hyper-lipaemic solutions. Their behaviou r when exposed to the detergent Tween 80 is similar to that of other acanthocytes but this finding is not pathognomonic of a lipid abnormality: other morphologically similar cells such as pyknocytes and burr cells occasionally regain a normal shape in the presence of detergents (Rowland, 1967).

The distinctive clinical feature of the normolipoproteinaemic syndrome is an extra-pyramidal movement disorder with dystonic, choreiform and athetoid movements and a wide variety of oro-facial tics. No swallowing difficulties were experienced in the patient described by Levine et al. (1968) although there were roving tongue movements and the speech was dysarthric and interrupted. The oro-pharyngeal abnormalities in the present patient are mild by comparison with those of the proband in the Kentucky family. He had a gnawed tongue and severe lacerations on his lips and held a rag to his mouth to prevent further damage. Since the original publication a further study of his swallowing difficulties has been made (Critchley, E.M.R., 1968, unpublished). He would initiate deglutition by throwing his head backwards to straighten the curvature of the oro-pharynx. In the cine-films, the partially amputated tongue was relatively immobile. Discordant movements were seen involving the tongue, palate and posterior pharyngeal wall but these failed to result in a normal peristaltic wave. Beyond the hypopharynx rhythmic muscular contractions were present.

The compulsive monosyllabic utterances in these patients never suggested coprolalia despite the disinhibiting influence of the dementia, but there is a close resemblance to the Gilles de la Tourette syndrome, and it is of interest that tongue biting has also been reported in this condition (Striner, 1927). We can anticipate the discovery of other patients with normolipoproteinaemic acanthocytosis if a wet preparation of the peripheral blood is examined on all patients with oro-facial tics and involuntary movements. The condition appears to follow an autosomal recessive mode of inheritance, and, in the other two families, there is evidence of partial expression in the heterozygous form. The importance of the syndrome lies in the association of chronic degenerative neurological disease with biochemical and haematological anomalies, largely unexplored, yet amenable to further study.

\section{Acknowledgments}

We wish to thank in particular, Doctors D. P. Oakley, A. F. Ollerenshaw, W. G. Owen, V. Bhushan and J. A. Gatt, B.Sc. at Preston Royal Infirmary for their help and interest, Dr J. K. Lloyd at Great Ormond Street Hospital for vitamin E estimations, Dr M. C. Stone at Leigh Infirmary for nephelometry, and Doctors A. J. Salisbury and J. A. Clarke at St Bartholomew's for electronmicroscopy. Requests for reprints should be addressed to E.M.R.C.

\section{References}

Betts, J.J., Nicholson, J.T. \& CRitchley, E.M.R. (1970) Acanthocytosis with normolipoproteinaemia: biophysical aspects. Postgraduate Medical Journal, 46, 702.

Critchley, E.M.R., Clark, D.B. \& Wikler, A. (1968) Acanthocytosis and neurological disorder without abetalipoproteinaemia. Archives of Neurology, 18, 134.

ENGel, W.K., LeVy R.I., WATKINS, S.P. \& VROOM, F.Q. (1967) Discussion: An adult form of acanthocytosis. Transactions of the American Neurological Association, 92, 135.

Estes, J.W., Morley, T.J., Levine, I.M. \& Emerson, C.P (1967) A new hereditary acanthocytosis syndrome. American Journal of Medicine, 42, 868.

Kuo, P.T. \& BASSETT, D.R. (1962) Blood and tissue lipids in a family with hypobetalipoproteinaemia. Circulation, 26, 660.

LEVINE, I.M. (1964) An hereditary neurological disease with acanthocytosis. Neurology, 14, 272.

LeVine, I.M., Estes, J.W. \& LoONEy, J.M. (1968) Hereditary neurological disease with acanthocytosis. Archives of Neurology, 18, 403.

Mars, H., Lewis, L.A., Robertson, A.L., Butkus, A. \& Williams, G.H. (1969) Familial hypobetalipoproteinaemia. American Journal of Medicine, 46, 886.

Phillips, G.B. (1962) Quantitative chromatographic analysis of plasma and red cell lipids in patients with acanthocytosis. Journal of Laboratory and Clinical Medicine, 59, 357.

Rovito, D.A. \& Pirone, F.J. (1963) Acanthocytosis associated with schizophrenia. American Journal of Psychiatry, 120, 182.

RowLAND, L.P. (1967) Discussion: An adult form of acanthocytosis. Transactions of the American Neurological Association, 92, 134.

Salt, H.B., Wolff, O.H., Lloyd, J.K. Fosbrooke, A.S., Cameron, A.H. \& Hubble, D.V. (1960) On having no betalipoprotein: A syndrome comprising abetalipoproteinaemia, acanthocytosis and steatorrhoea. Lancet, ii, 325.

Stone, M.C. \& ThORP J.M. (1966) A new technique for the investigation of the low density lipoproteins in health and disease. Clinica et Chimica Acta, 14, 812.

Stone, M.C., Thorp, J.M., Mills, G.L. \& Dick, T.B.S. (1970) Clinica et Chimica Acta. (In press.)

STRINER, E. (1927) Utersuchungen uber die postchoreatischen Motilitatsstorungen, insbesondere die Beziehungen der Chorea minor zum Tic. Monatsschrift fur Psychiatrie und Neurologie, 66, 71. 